\title{
Szilvia Barta
}

\section{The Comedy of the Tragic}

\author{
Anticipations of the Theatre of the Absurd \\ in William Butler Yeats's The Death of Cuchulain
}

Since William Butler Yeats is most often classified as a writer of poetic or symbolist drama, an attempt to search for absurdist elements in his plays may seem a rather dubious enterprise. I must also keep in mind the judgement of many of his critics that he is a minor figure as a dramatist. Thus, my intention is twofold, to argue that Yeats's drama anticipates certain constituents of the Theatre of the Absurd, and to propose a more positive positioning of Yeats as a dramatist. By "constituents" I mean the elements of both drama and theatre, and not textual borrowings of the playwrights of the Theatre of the Absurd from Yeats's plays and poems, such as the titles of Beckett's plays ... but the clouds ..., or Words and Music. Such an approach is thwarted by Beckett himself when he rejects any connection between the characters of The Cat and the Moon and Waiting for Godot. ${ }^{1}$ Yet there are scholars who claim that Yeats's dramaturgy includes absurdist principles. Richard Taylor, for instance, suggests in The Drama of W.B. Yeats that "his methods of poetic compositions and stage representations have influenced the recent flowering of the Theatre of the Absurd." In British Drama 1890 to 1950 R.F. Dietrich draws a similar conclusion about Yeats's role in creating a "total theatre" ${ }^{3}$ while, to reverse the analogies mentioned above, Ch. Innes in Modern British Drama 1890-1990 argues that Beckett's art is "the

1 Deirdre Bair, Samuel Beckett. A Biography (London: J.Cape, 1978) p. 383.

2 Richard Taylor, The Drama of W.B.Yeats. Irish Myth and Japanese No (London: Yale UP, 1976) p. 187.

${ }^{3}$ Richard F. Dietrich, British Drama 1890 to 1950. A Critical History (Boston: Twayne, 1989) p. 184. 
extension of the symbolist line in British poetic drama from W.B. Yeats to T.S. Eliot." ${ }^{4}$

Among the few comparative studies devoted to discover the interrelation between the Irish dramatists, Katharine Worth's The Irish Drama of Europe from Yeats to Beckett even in the title suggests her attitude towards the two playwrights. Saying that "it is a narrow view to look at Yeats's dramas as part of only the 'Irish Dramatic Movement' as Una Ellis-Fermor does in The Irish Dramatic Movement," Worth associates him with Craig, Maeterlinck, Artaud, Beckett and the contemporary director, Brook. ${ }^{5}$ At the same time, she lays emphasis on the elements of dramaturgy, like the "double-effect" as present in both Yeats and Beckett. That my hypothesis is not far-fetched can also be justified by the correspondences between the Theatre of the Absurd and other Irish writers. One of these analogies is mentioned by Dietrich who interprets Wilde's The Importance of Being Earnest as "the epitome of standing things on their heads."7

As it must have become clear from the comments quoted above, there are various dimensions in Yeats's drama that resemble certain experiments of modernist theatre. In the following, concentrating on The Death of Cucbulain, I would like to throw some light on these modernist tendencies in Yeats's poeticsymbolist play.

\section{THE HERO AND HIS METAPHORS}

The Cuchulain legend was one of Yeats's earliest discoveries. In the nineties he accumulated the primary figures of the "iconography of the Cuchulain cycle": the fool, the guardian and the shape-changing birds of ambiguous omen. ${ }^{8}$ Since he was conscious of the spiritual regeneration of Ireland, he planned the Irish Mystical Order but gave up the project in 1903. During the Irish Literary Movement Yeats became an "amateur folklorist." He roamed over the country and noted the songs, poems, and stories of the village people. However, his interest and approach to Irish folklore and saga material - which was primarily

4 Christopher Innes, Modern British Drama 1890-1990 (Cambridge: Cambridge UP, 1992) p. 428.

${ }^{5}$ Katharine Worth, The Irish Drama of Europe from Yeats to Beckett (London: University of London, 1978) pp. 1-2.

6 Worth p. 259.

7 Dietrich p. 70.

${ }^{8}$ Reg Skene, The Cuchulain Plays of W. B. Yeats. A Study (London: Macmillan, 1974) pp. 11f. 
inspired by Sir James Frazer's The Golden Bough - "have aroused much ridicule among Celtic scholars." They did not seem to approve of Yeats's conception of the Irish literary and social revival and of his idea of folklore forming the real unity of a nation.

In studying the Cuchulain legend, Lady Gregory and her collection Cuchulain of Muirthemne provided Yeats with the mythological plot of the plays. Lady Gregory was another enthusiastic "collector" of Irish tales. Her works, though lacking critical evaluation, include a great variety of themes like visions and beliefs, gods and fighting men, saints and wonders. Yeats wrote a series of dance-plays based on the Cuchulain cycle: On Baile's Strand (1903), The Green Helmet (1910), At the Hawk's Well (1917), The Only Jealousy of Emer (1919), The Death of Cuchulain (1939). But other plays are linked with fragments of Irish mythology like Deirdre, and The Herne's Egg. The Cuchulain plays are mostly studied as parts of a series because they are claimed to mark the crisis points of Yeats's life. Reg Skcne and Birgit Bjersby were concerned with analysing the Cuchulain plays as a "psychological biography."

I wish to concentrate on The Death of Cuchulain, as it develops what Yeats had already implied in The Herne's Egg, that is, the destruction of the heroic. The first draft of the play was completed in September 1938 and Yeats finished it one month before his death on 28 January, 1939. In a letter to Ethel Mannin he describes his intentions on the presentation of the play: "I am writing a play on the death of Cuchulain; an episode or two from the old epic. My "private philosophy' is there but there must be no sign of it; all must be like an old faery tale... ." In another letter written in January Yeats refers to the play as "strange and the most wooing" he had written for years (Letters, pp. 917-8.). It is true, the Cuchulain story which earlier serves as the ideal of heroism and the Celtic Revival becomes an image of destruction and loneliness in The Death of Cuchulain. But who was Cuchulain?

He earned his fame as the "Hound of Ulster," and his deeds are told in the Ulidian Heroic Tales that, as Gerard Murphy claims, find their parallels in Greek epic literature. ${ }^{10}$ The "Irish Achilles" was celebrated as the symbol of the nationalist movements. Patrick Pearse, James Connolly, and even Yeats identified themselves with the image of Cuchulain during the Easter Rising in 1916, while

\footnotetext{
9 Bjersby, Birgit: The Interpretation of "The Cuchulain Legend" in the Works of W. B. Yeats (Upsala: Upsala UP, 1950) p. 7.

${ }^{10}$ Gerard Murphy, Saga and Myth in Ancient Ireland (Dublin: Colm O. L., 1961) p. 26.
} 
his female counterpart, the Countess Cathleen was represented by Maud Gonne. In his poetry and drama Yeats's personal and impersonal visions are projected into the hero who was partly the object of a heroic "cult," partly the metaphor of Yeats's inward struggles. The Cuchulain-image, however, gradually changed. In "The Circus Animal's Desertion" the poet recollects the heroes of the Irish mythology as "stilted boys," and "themes of the embittered heart"(pp. 391-2). As an irony of fate, Cuchulain - previously symbolizing the faith of modern Ireland - was cast into bronze to commemorate the unsuccessful Easter Rising. He became a "mummy-dead," one of "those old kettles, old bottles, and a broken can / old iron, old bones, old rags." In the poem Yeats describes the heroic deeds of Cuchulain with a sense of irony:

And when the Fool and Blind Man stole the bread

Cuchulain fought the ungovernable sea;

Heart-mysteries there, and yet when all is said

It was the dream that enchanted me.

(pp. 391-2)

The mythical hero degenerates in The Death of Cuchulain. Yet Skene states that the play remains a "monument, to the noble dream of an Irish nation founded on a 'heart-uplifting pride' rather than on hatred, envy, bitterness and suspicion of a land." Although Yeats's play does not express hatred and envy, Cuchulain's death at the hands of the Blind Man, which recalls Congal's pathetic death in The Herne's Egg, cannot be interpreted as a "noble dream" or the manifestation of "heart-uplifting pride" but as the irony and the bitterness of the poet. By the end of Yeats's life, Cuchulain became "the statue" reviving the spirit of political and personal failures. A letter from April 1935 with a reference to Toller's plays shows Yeats's insistence on the theme of the revolution and his sympathy for a different dramatic experiment.

My great sensation of recent weeks has been Toller's Seven Plays ... Hoppla and The Blind Goddess prove that Toller has taken up drama as it came from Ibsen and transposed it completely (turning towards the crowds) as Pirandello (turning towards the individual). (Letters p. 833.)

Ernst Toller's play, Hoppla Wir Leben!, reflects on the German Revolution in 1918-19. Toller himself, a member of the German expressionist movement, participated in the revolution as a commander of the Red Guard. But

\footnotetext{
"Skene p. 21.
} 
by the time Hoppla was completed in 1927, his enthusiasm and illusions turned into a tragi-comic feeling. Therefore, Toller's mood possibly resembled the attitude of the Irish dramatists, O'Casey and Synge, and consequently must have had an important impact on Yeats's anti-heroes.

\section{ILLUSION AND RITUAL}

The Death of Cuchulain opens with a prologue told by an Old Man "looking like something out of mythology"(p. 693). His speech as a dramatic innovation of the seventy-three-year old poet combines two functions. First, it implies Yeats's selfirony since he "looks back over a lifetime devoted to the attempt to re-establish ritual verse-drama in the modern theatre, in the face of the public preference for melodrama, realism and satire." 12 The ideals celebrated in the previous era are transformed into an "antiquated stuff" which is "out of fashion," while the Old Man enumerates the critical comments on Yeats's dramatic work. The prologue also functions as a "dramatic mirror" that has a double-effect. On the one hand it evokes laughter, on the other hand it awakens the awareness of the audience by quoting their own critical remarks. The same double-effect is achieved by the social clichés repeated in the Theatre of the Absurd. In All That Fall, for instance, Mrs Rooney turns to everyone on her way with the same question: "How is your poor mother?" (p. 177.) Her "mechanicalism" sounds comic, however, the spectator may realize that the laughing-stock - the clichés and the criticism retold by Mrs. Rooney and the Old Man - actually derives from those who laugh at it.

After confronting past and present in the prologue, the Old Man forecasts the events: "I promise a dance," "there must be severed heads" (p. 694). He drafts the plot and the scenery, instructs the movement of the dancers, and introduces the musicians. He is the "director" as he was "asked to produce a play"(p. 693). The introduction of the Old Man as the "Master of Revels" creates a distance between the drama and the audience, for he emphasizes that it is a well-directed performance, not reality, that the audience is going to see. Thus the prologue functions like the Brechtian "Verfremdungseffekt" removing the viewers from the illusiory world of drama. As the alienation is already present in the critical remarks of the Old Man, Skene's idea to put Yeats's mask upon the Old Man in his production of The Death of Cuchulain seems to reverse and neutralize the

\footnotetext{
${ }^{12}$ Skene p. 222.
} 
intended effect. ${ }^{13}$ The prologue is separated from the rest of the events, as the Old Man never emerges again. There is a similar introduction in A Full Moon in March in which two attendants arrive arguing about what song the director wished for. In the play, then, they act as the servants of the Queen, which implies the narrow border between reality and illusion. Their dialogue, like the Old Man's prologue may raise the problem of creation, although the characters slip into a new role with much confidence. They are not puzzled by their transitional state like the actors in Pirandello's Six Characters in Search for an Author.

In the prologue the Old Man predicts Emer's dance with severed heads. Beheading, blood-sacrifice were equally part of the ritualistic ceremony of the Celtic warriors. The rite springs from the heroic age, along with the characters: Cuchulain, Eithne Inguba, Maeve (Aoife), Emer and Morrigu. The women encircle Cuchulain in a "fatal dance," because, as he says, "Women have spoken so, plotting a man's death" (p. 698). Finally, wounded by six men he is tied to a pillarstone, like Prometheus, with Aoife's veil. But the ritualistic sacrifice of the hero is abruptly interrupted by the Blind Man who kills Cuchulain for twelve pennies. This anti-heroic moment may be the reason why Taylor defines the play as a "thorough revision of The Herne's Egg." ${ }^{4}$ After his inglorious death, Cuchulain is resurrected in Emer's dance that is not comic like the Lame Beggar's rite in The Cat and the Moon, but a moment of "pure theatre." Emer's dance rather recalls the conclusion of $A$ Full Moon in March where the Salomé-like Queen dances with the head of a Swineherd she has killed.

The dance as a climactic point in the plot begins the ritualistic cycle of life and death in The Cat and the Moon and in At Full Moon in March. But in The Death of Cuchulain it is followed by the loud music of an Irish fair through which the illusion is broken. Northop Frye in his essay on Shakespearean tragedies emphasizes music as the symbol of the Apollonian world, and thus harmony, order, and stability. Linking the metaphors of harmony with social order he continues: "the passing of such an order is regularly symbolized by music." Departing from Frye's concept the concluding song can be interpreted as the revelation of a new age or the meditation on the interrelation of an old and a subsequent period. ${ }^{15}$ Wilson argues for the song being the keypoint in the play,

\footnotetext{
${ }^{13}$ Skene p. 123. (A production of The Death of Cuchulain staged by the author at the University of Winnipeg in 1969.)

14 Taylor p. 188.

${ }^{15}$ Northrop Frye, Fools of Time (Toronto: Toronto UP, 1977) p. 23.
} 
and this may be relevant because it relates the fable of Cuchulain to contemporary Ireland. ${ }^{16}$

\author{
What stood in the Post Office \\ With Pearse and Connolly? \\ What comes out of the mountain \\ Where men first shed their blood? \\ Who thought Cuchulain till it seemed \\ He stood where they had stood?
}

(pp. 704f)

The lines draw attention to the responsibility of the leaders of the Easter Rising, while the Cuchulain-legend sets an example for the Irish who might have remembered Cuchulain not merely as a hero but a man whose death turned into the mockery of heroism. From this angle, Wilson's argument about the song as a "keypoint" could be paraphrased so that the interrelation of the song, the fable and contemporary Ireland is at the heart of the play.

Music and dance organize the ritual in The Death of Cuchulain as well as in The Player Queen and The Cat and the Moon. In Yeats's drama music may deliver a symbolic message - the "passing of an order" as Frye describes - which may be embedded in the structure of the plot, or the ideas of the characters. In the songs and the ritualistic dances inexpressible thoughts and emotions come to the surface, because one can be

dancing as if language had surrendered to movement ... as if the very heart of life and all its hopes might be found in those assuaging notes and those hushed rhythms. ${ }^{17}$

Emer's last dance is precisely instructed by Yeats:

Emer runs in and begins to dance. She so moves that she seems to rage against the heads of those that had wounded Cuchulain....going three times round the circle of the heads. She then moves towards the head of Cuchulain ... she moves as if in adoration or triumph.

Yeats's consciousness of movement is a modernist approach in the theatre, since he pointed out the importance of body language as a means to express emotions. $\mathrm{He}$ did not invent any new principles, but by returning to the ritualistic dance

\footnotetext{
${ }^{16}$ Wilson, 'W.B. Yeats and Tradition' in Peter Ure, Yeats the Play wright (London: Routledge, 1969) p. 78.

${ }^{17}$ Brian Friel, Dancing at Lughnasa (London: Faber and Faber, 1988) p. 71.
} 
that is "united" with the mind, he discovers how the player is able to enact his or her Self. Beckett's plays composed with musical effects, like Words and Music, also reflect the inner life of the characters. Yet, as life in the Theatre of the Absurd is degraded, in Words and Music the sounds of a rapping baton, and a thumping club can be heard instead of harmonic melodies. In Yeats's The Herne's Egg music accompanies the mock-heroic fight of the two kings, which can be similarly considered as a means to express the chaotic world and the disintegration of Self.

\section{DREAMS AND MEMORIES}

It was only by watching my own plays upon the stage that I came to understand that this reverie, this twilight between sleep and waking, this bout of fencing, alike on the stage and the mirrd, between man and phantoms ... is the condition of tragic pleasure. (Uncollected Prose p. 389.)

Yeats describes dreams as if he instructed the figures of The Death of Cuchulain who move between "sleep and waking." The characters "appear and disappear inconsequentially," and their memories form the three levels of time in the play in which Cuchulain's past and present are subordinated to the reality of the Old Man. ${ }^{18}$ Yeats adopted the technique of "dreaming back" from the Noh drama to confront his protagonists with their previous life. Cuchulain recalls his encounter with Aoife At the Hawk's Well, and his son's death that constantly haunts him. Because of the illogical mixing of past and present The Death of Cuchulain is not only an adaptation of a fable but a drama of the inner self in which the characters give an account of their lives. As Krapp does in his last recording. In Beckettian plays the "being of man" is emphasized as Worth points out. ${ }^{19}$ From this aspect, Yeats's Purgatory and The Death of Cuchulain correspond to All That Fall or Waiting for Godot, but to Rosencrantz and Guildenstern as well. The characters of these plays make an attempt to remember and free themselves from their dreadful memories.

Cuchulain's recollection of the events and the prominent figures of his life fails sometimes, so Aoife asks: "Am I recognized?" (p. 699) The hero who used to fight the ungovernable sea, seems to be troubled by the burden of killing his only son. His consciousness of guilt reminds one of Mrs. Rooney in All That Fall who

\footnotetext{
${ }^{18}$ Bjersby p. 100.

${ }^{19}$ Worth p. 244.
} 
also conceals something: "oh if you had my eyes ... you would understand ... the things they have seen ... and not looked away" (p. 185). Failing to recognize each other may also create comic situations, for instance, in Rosencrantz and Guildenstern:

HAMLET: My excellent good friends! How dost thou Guildenstern? (Coming downstage with an arm raised to Ros, Guil meanwhile bowing to no greeting. Hamlet corrects bimself. Still to Ros.) Ah Rosencrantz! (They laugh good-naturedly at the mistake.)

Like Cuchulain, Ros and Guil relive their memories in order to indentify themselves. However, by the time they find their identity, they have to die. Besides failing memory, the hero is weakened by the presence of the malevolent war goddess, Morrigu who is the ultimate power inciting the women to kill Cuchulain. In the first scene she stands between him and Eithne disturbing the conscience of the latter. Frye's reference to ghosts, omens and magic implies that they-

threaten our sense of reality with madness: as things conceived, they show up the limited and finite nature of the human perspective, especially in thought. Thus they emphasize the existential irony in tragedy by showing that there are always more things to be experienced than philosophy can digest. ${ }^{20}$

Cuchulain is unaware of the evil ghost, it is Eithne who feels "that somebody or something is there / Yet nobody that [she] can see" (p. 696). The "blindness" of the hero may be "the existential irony" of his fate, but at the same time it shows his inability to apprehend the deity. Cuchulain and King Congal have to face "a ghost as a clinging presence," as Worth says, "an emanation from some obscure region of consciouness or a mysterious continuation of mind outside the body." It is this definition of the supernatural on the basis of which Worth finds a resemblance between the plays of Beckett and Yeats. ${ }^{21}$

As a counterpoint to the confusion of the "seeing" characters the Blind Man enters the stage who represents the real world. He is bright, and witty, and even Cuchulain states "that the blind Know everything" (p. 702). The spontaneous movements of the Blind Man such as feeling Cuchulain's body to find a right place to stab him do not mirror the hopeless stumbling of the hero

\footnotetext{
${ }^{20}$ Frye p. 24.

${ }^{21}$ Worth p. 253.
} 
among dreams and memories, but the possibility for him to survive. Ros and Guil discover this possibility standing in darkness:

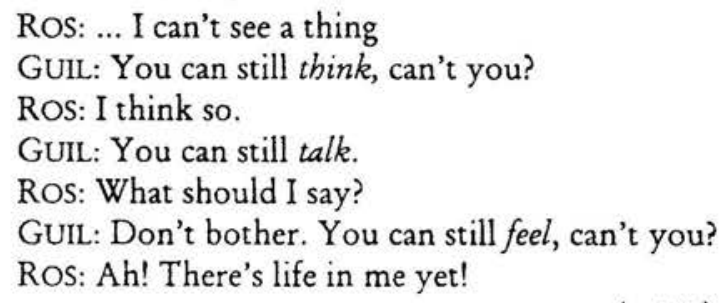

"There's life in me yet" - it could be said by the old man in Maeterlinck's play The Intruder who can feel that something evil has happened in the family although they refuse to tell him. Worth suggests that Beckett and Pinter inherited the importance of blindness from Maeterlinck, as a state when our inner self is more intensive. ${ }^{22}$ The blind, as Cuchulain believes, "know everything," and in the Greek tradition even the role of the "vates" was attributed to them. Yeats's blind figures derive from mythology and symbolism, but lacking the traditional attributes of the "vates" they are greedy and witty, and their mock-heroic position enables them to execute the protagonists for a few pennies.

\section{THE "DEATH" AND THE HERO}

In the introduction I suggested that the Cuchulain-image as the symbol of faith was degraded in Ireland. In The Death of Cuchulain the heroic is degraded on two levels: in the hero's relation to the goddess and to his death. As both aspects are manifested in an ironic tone, Cuchulain's death ends in a feeling of tragi-comedy. With black magic Morrigu, the war goddess falsifies Emer's message, which confuses Cuchulain. Although he declares that "I make the truth," repeating Congal's statement "I am the Court," the hero cannot recognize whether Emer or Eithne betray her, or whether his battle and love are in vain.(p. 698) For lack of a sense of reality and truth, Cuchulain is close to the "contemporary view of man's unprotected situation in a hostile universe. ${ }^{23}$ It is not his heroic aspiration, but his nature of being that is illuminated when he is opposed to the monstrous, invisible

22 Worth p. 210.

23 Taylor p. 199. 
and fatal power of the goddess. Frye, commenting on the Greek gods explains that they-

are to human society what the warrior aristocracy is to the workers within human society itself. Like aristocrats, they act towards their inferiors with a kind of rough justice. [so] as long as the gods are there, man is limited in his scope, ambitions and powers. ${ }^{24}$

Morrigu acts with the "rough justice" of the Greek gods, so Cuchulain is sentenced to death. In the plays of the Theatre of the Absurd there are similar symbolic deities, and the characters are mostly aware of that "we are little men, we don't know the ins and outs of the matter" (p. 81.), as Guildenstern expresses the limited condition of the human being.

Ben and Gus in The Dumb Waiter stand motionless, "paralyzed" by the power of the unknown. Cuchulain's attitude to death may be described as an exhibition of "heroic generousity and heroic calm," while he, unlike King Congal, faces death with a kind of indifference. ${ }^{25}$ The existential danger embodied by an old man having a "lucky day" forces him to come face to face with "Death" not in a heroic battle but in an absurd encounter with the blind anti-hero. The legendary hero becomes conscious of his finite nature, yet he cannot fully identify himself. Deprived of his fame he has to come to terms with death like Rosencrantz and Guildenstern, being alone in an unfamiliar reality, and degraded as a human being.

Yeats's plays do not restrictively belong to the poetic-symbolist tradition, but they mingle the tragic, the symbolic, the tragicomic and the grotesque. These attributes are all closely associated with the Theatre of the Absurd. The tragicomic may simply mean the co-existence of the tragic and the comic in a play, but Yeats, however, achieves the inversion of these two. In The Cat and the Moon, when a lame and a blind beggar are hopping hopelessly like puppets, the serious attempt of two retarded men to meet the saint is comically contrasted with their awkward movements. Yeats deliberately referred to "puppet stage" instructing the Lame Beggar's bodily movements in the farcical scenes, when, for instance, the Blind Beggar chases the Lame Beggar swinging his stick. Tragedy and comedy do not stand far apart in this "clowning" but it awakens a mixed feeling

\footnotetext{
${ }^{24}$ Frye p. 7.

${ }^{25}$ Leonard E. Nathan, The Tragic Drama of W. B. Yeats. Figures in Dance (London: Columbia UP, 1965) p. 201.
} 
like most absurdist plays. Kott, commenting on the Theatre of the Absurd, introduces a new theatrical genre - "ridiculous-tragic" - and explains the confusing tone with Ionesco's thought:

I have never understood the difference people make between the comic and the tragic. As the 'comic' is an intuitive perception of the absurd, it seems to me more hopeless than the 'tragic.' The 'comic' offers no escape. $^{26}$

In the prologue of The King's Threshold, which was omitted from the final version of the play, Yeats writes about

the stage ... filled with great ladies and gentlemen ... as if there was no such thing in the world as cold in the shoulders, and speckled shins, and the pains in the bones and stiffness in the joints. ${ }^{27}$

This passage implies the double reference of the tragi-comic nature of life that is a common element of the Theatre of the Absurd and the Yeatsian plays. Tragicomedy even turns into an image of the grotesque in The Death of Cuchulain, where the heroic is degraded in a senseless, destructive world. The inversion of the tragic and the comic results in a distortion, the desecration of the myth, which becomes the grotesque alternative of Yeats's first plays, The Countess Catbleen and The Catbleen ni Houlihan. The grotesque appears in several forms in The Death of Cucbulain: in the exaggerated and distorted picture of the human figure, as part of the nihilistic worldview, or as "the quest for the lost unity.".

The dramatic structure in Yeats becomes a "parody" of the conventional plot because it either represents an inverted order of society or a linear pattern of events with anti-climactic points. In The Death of Cuchulain the theatrical technique of the play-in-a-play governs the plot, in which the three levels of time are also underlined by the "intrinsic strangeness" of the characters. ${ }^{29}$ It is the unity of the real and the unreal, the spontaneous and the conscious, as Worth suggests, that results in the "double-effect" so closely associated with both the Yeatsian and the Beckettian characters. ${ }^{30}$ Supernatural deities like the Morrigu do not emerge as

\footnotetext{
${ }^{26}$ Jan Kott, The Theatre of Essence (Evanston: Northwestern UP, 1984) p. 98.

${ }^{27}$ Innes p. 365.

${ }^{28}$ Dietrich p. 682. (my translation)

${ }^{29}$ Innes p. 363.

${ }^{30}$ Worth p. 259.
} 
aiding spirits but rather as the unknown menace evoking man's existential fears in the incomprehensible universe. Csilla Bertha highlights this point holding that-

the fantastic elements [in Yeats's plays] help to bring to the surface indefinite longings for the unknown, fears of superior powers or the tragedy of human helplessness in this fallen world.

The existentialist philosophy generally considered as the spiritual source of the Theatre of the Absurd manifests a similarly degraded role of man in the modern world. Deprived of his sense of logic and willpower he is forced into the great mechanism of life. So he is obsessed with anxiety, loneliness, the fear of death, boredom and the feeling of the absurd. This corresponds to Yeats's philosophy of cyclical history. He believed that he was "out phase," because his phase was not identical with that of his age. Therefore he had to face the incongruity of the world. Yeats's disillusionment with the "decrepit age that has been tied to [him] / As to a dog's tail," may have compelled him to search for modernist principles of the theatre and dramaturgy. And it is these aspects, the devaluation of man and mythology, and the nontextual techniques borrowed from the Noh drama like song, dance, mask, puppet-like movement, and theatrical games, through which I could truly regard Yeats's dramatic imagination as the anticipation of the Theatre of the Absurd.

${ }^{31}$ E. Donald Morse, ed. by Csilla Bertha, Worlds Visible and Invisible (Debrecen: Kossuth UP, 1994) p. 11. 